\title{
Risk Factors of Anemia in Pre-end-Stage Renal Disease
}

Mohammed M. Nussier ${ }^{1}$, Hosni A. Younis ${ }^{1}$ and Mohammed S. Allam ${ }^{2}$

${ }^{1}$ Internal Medicine, and ${ }^{2}$ Clinical Pathology Departments

Faculty of Medicine, Al-Azhar Assiut University, Egypt

Corresponding author: Mohammed M. Nussier,

Internal Medicine Department, Faculty of Medicine, Al-Azhar Assiut University, Egypt

\begin{abstract}
Background: Anemia is a common complication of chronic kidney disease (CKD). Observational studies indicate that low $\mathrm{Hb}$ levels in such patients may increase risk for progression of kidney disease and cardiovascular morbidity and mortality. Objective: The aim of the work is to study the different risk factors contributing to anemia in preend stage renal disease patients (stage 3 and 4 CKD).

Subjects and methods: The study involved 50 patients with history of CKD, not receiving any treatment or dialysis, 29 men and 21 women, 22-72 years old. In addition to 20 healthy persons as a control group. They were randomly selected from the outpatient clinics and inpatient department of Internal Medicine Departments, Al-Azhar Assiut University Hospitals over a period of two years.

Results: There were different risk factors causing anemia among patients group; 1-Anorexia was present in (44\%) of patients, 2-Fecal occult blood test was positive in $(6 \%)$ of patients, 3-The indicators of inflammation including high levels of CRP, ESR (were high in 100\%) and serum ferritin was high in (80\%) of patients, 4-The indicators of "uremic milieu" including increased level of blood urea and S. creatinine and moderate to severe albuminuria in addition to decreased level of GFR, all were present in (100\%) of patients, and 5-erythropoietin deficiency also was present in (54\%) of patients. Conclusion: Our study concluded that anemia in pre end stage renal disease (ESRD) is multifactorial and the prevalence of different risk factors is inversely correlated with hemoglobin level.
\end{abstract}

Keywords: Risk Factors, Anemia, Pre-end Stage Renal Disease.

\section{INTRODUCTION}

Chronic kidney disease (CKD) is an important, chronic disease that affects humans all over the world. It is characterized by irreversible impairment of excretory, metabolic and endocrine functions of the kidney leads to the development of clinical syndrome of uremia ${ }^{(\mathbf{1})}$. Anemia is a common complication of CKD. The prevalence of anemia varies with the degree of renal impairment in pre-dialysis patients with CKD, but once end-stage kidney failure occurs, all patients are eventually affected ${ }^{(2)}$. Anemia develops once renal function decreases to $50 \%$ because of a deficiency in endogenous erythropoietin production by the kidney, decreased red cell survival, blood losses, and increased red blood cell destruction once the patients begin dialysis treatment, particularly hemodialysis (3). Observational studies indicate that low $\mathrm{Hb}$ levels in such patients may increase risk for progression of kidney disease and cardiovascular morbidity and mortality ${ }^{(4)}$.

\section{AIM OF THE WORK}

The aim of the work is to study the different risk factors contributing to anemia in pre-end- stage renal disease patients (stage 3 and $4 \mathrm{CKD}$ ).

\section{SUBJECTS AND METHODS}

Subjects: The study involved 50 patients with history of (CKD), not receiving any treatment or dialysis, 29 men and 21 women, 22-72 years old. In addition to 20 healthy persons as a control group. They were randomly selected from the outpatient clinics and inpatient department of Internal Medicine Departments, Al-Azhar Assiut University Hospitals over a period of two years.

Inclusion criteria: Patients with documented chronic kidney disease of: serum creatinine $\geq 2 \mathrm{mg} / \mathrm{dl}$, GFR < 60 and $>15 \mathrm{~mL} /$ minute $/ 1.73 \mathrm{~m}^{2}$ ( i.e. CKD stage III and IV(pre ESRD).

Exclusion criteria; for patients group: patients with ESRD or those on dialysis.

For both patients and control groups:

- Recent severe hemorrhagic episode.

- Recent blood transfusion

- patients receiving iron or erythropoietin therapy

- Malignancy or known hematological disorder

\section{Methods:}

Ethical consideration and Written informed consent:

An approval of the study was obtained from AlAzhar University academic and ethical committee. Every patient signed an informed written consent for acceptance of the operation.

\footnotetext{
After providing informed consent, all subjects were subjected to:

1-Full history taking with stress on nutritional history and anorexia, history of chronic diseases, any drug use, stigmata of CKD.

2- Complete physical examination and assessment of body mass index.

3-Abdominal US.
} 
4-Laboratory investigations including; CBC, ESR, Creactive protein, $\mathrm{S}$. albumin and total protein, $\mathrm{S}$. potassium and Kidney function tests, urinary albumin-creatinine ratio in early morning spot urine sample, overt proteinuria by dipstick method and stool examination for occult blood, iron measurements including : S. iron, S. ferritin, total iron binding capacity and transferrin saturation percent, and erythropoietin assay.

5-Estimation of (GFR) using the CKD-EPI (Chronic Kidney Disease Epidemiology Collaboration) formula.

\section{Statistical analysis}

Recorded data were analyzed using the statistical package for social sciences, version 20.0 (SPSS Inc., Chicago, Illinois, USA). Quantitative data were expressed as mean \pm standard deviation (SD). Qualitative data were expressed as frequency and percentage.

\section{The following tests were done:}

- Independent-samples t-test of significance was used when comparing between two means.

- Chi-square $\left(\mathrm{x}^{2}\right)$ test of significance was used in order to compare proportions between two qualitative parameters.

- The confidence interval was set to $95 \%$ and the margin of error accepted was set to $5 \%$. The p-value was considered significant as the following:

- Probability (P-value)

- P-value <0.05 was considered significant.

- $\quad$ P-value $<0.001$ was considered as highly significant.

- $\quad$ P-value >0.05 was considered insignificant.

\section{RESULTS}

1- Our results revealed other chronic diseases and anorexia in the studied patients as shown in Table 1.

Table (1): Past and nutritional history in the studied patients

\begin{tabular}{|l|l|l|}
\hline \multicolumn{1}{|c|}{ Parameter } & No. $(\mathbf{n = 5 0})$ & \% \\
\hline Diabetes mellitus & 26 & 52.0 \\
\hline Hypertension & 26 & 52.0 \\
\hline Ischemic heart diseases, & 11 & 22.0 \\
\hline Rheumatoid arthritis & 2 & 4.0 \\
\hline Rheumatic heart disease & 1 & 2.0 \\
\hline $\begin{array}{l}\text { Systemic lupus } \\
\text { erythematosus }\end{array}$ & 8 & 16.0 \\
\hline Anorexia & 22 & 44.0 \\
\hline
\end{tabular}

2- The clinical signs in the studied patients included: pallor, facial puffiness, lower limbs edema and other clinical signs as illustrated in table (2).

Table (2): Physical examination of the studied patients

\begin{tabular}{|l|c|c|}
\multicolumn{1}{|c|}{ Parameter } & $\begin{array}{c}\text { No. } \\
(\mathbf{n = 5 0})\end{array}$ & \% \\
\hline Pallor: & $\mathbf{5}$ & \\
Absent & $\mathbf{4 5}$ & \\
Present & $\mathbf{2 9}$ & \\
\hline Facial puffiness: & $\mathbf{2 1}$ & \\
Absent & & \\
Present & $\mathbf{3 1}$ & \\
\hline Lower limbs edema: & $\mathbf{1 9}$ & \\
Absent & & \\
Present & $\mathbf{8}$ & \\
& $\mathbf{3}$ & \\
\hline Others: & $\mathbf{1}$ & \\
Basal lung crepitations & $\mathbf{1}$ & \\
Cushioned face Malar & $\mathbf{3 7}$ & \\
flush & & \\
Mitral regurge & & \\
No other clinical signs & & \\
&
\end{tabular}

3- Our study revealed (Table 3):

- Highly significant differences between patients and control in $\mathrm{Hb}, \mathrm{HCT}$, RBCs count, $\mathrm{MCH}$, $\mathrm{MCHC}$ and reticulocyte count. All of these are higher in control than patients.

- Significant differences between patients and control in platelets count; it is higher in the control than patients group.

- No significant differences between patients and control in WBCs count and MCV.

- Highly significant differences between patients and control in complete haemogram $(\mathrm{CHg})$ as follows: the prevalence of anemia is higher in patients group than control. 
Table (3): Hematology Panel

\begin{tabular}{|c|c|c|c|}
\hline & $\begin{array}{c}\text { Patients } \\
(n=50)\end{array}$ & $\begin{array}{l}\text { Control } \\
(n=20)\end{array}$ & $\begin{array}{c}\text { P- } \\
\text { value }\end{array}$ \\
\hline $\begin{array}{l}\text { HB }(\mathbf{g} / \mathbf{d l}): \\
\text { Mean } \pm \text { SD }\end{array}$ & $\begin{array}{c}10.20 \pm \\
1.22\end{array}$ & $\begin{array}{c}14.02 \pm \\
1.40\end{array}$ & $0.001 *$ \\
\hline $\begin{array}{l}\text { Hematocrit value } \\
(\%) \\
\text { Mean } \pm \text { SD }\end{array}$ & $\begin{array}{c}32.26 \pm \\
3.63\end{array}$ & $\begin{array}{l}41.21 \pm \\
4.05\end{array}$ & $0.001 *$ \\
\hline $\begin{array}{l}\left.\text { WBCs }(\mathbf{x ~ 1 0})^{3}\right): \\
\text { Mean } \pm \text { SD }\end{array}$ & $\begin{array}{c}6.06 \pm \\
1.49\end{array}$ & $\begin{array}{c}6.63 \pm \\
1.36\end{array}$ & 0.120 \\
\hline $\begin{array}{l}\text { Platelets }\left(\times 1^{3}\right): \\
\text { Mean } \pm \text { SD }\end{array}$ & $\begin{array}{l}222.86 \\
\pm 42.33\end{array}$ & $\begin{array}{r}248.40 \\
\pm 36.43\end{array}$ & $0.021 *$ \\
\hline $\begin{array}{l}\left.\text { RBCs ( } \times 1^{6}\right): \\
\text { Mean } \pm \text { SD }\end{array}$ & $\begin{array}{l}4.22 \pm \\
0.28\end{array}$ & $\begin{array}{l}4.79 \pm \\
0.41\end{array}$ & $0.001 *$ \\
\hline $\begin{array}{l}\text { Mean } \\
\text { corpuscular } \\
\text { volume } \\
\text { (femtoliter): } \\
\text { Mean } \pm \text { SD }\end{array}$ & $\begin{array}{c}85.74 \pm \\
7.64\end{array}$ & $\begin{array}{c}83.84 \pm \\
5.11\end{array}$ & 0.128 \\
\hline $\begin{array}{l}\text { Mean } \\
\text { corpuscular } \\
\text { hemoglobin } \\
\text { (picogram/cell): } \\
\text { Mean } \pm \text { SD } \\
\end{array}$ & $\begin{array}{c}28.19 \pm \\
2.20\end{array}$ & $\begin{array}{c}29.55 \pm \\
1.83\end{array}$ & $0.008 *$ \\
\hline $\begin{array}{l}\text { M mean } \\
\text { corpuscular } \\
\text { hemoglobin } \\
\text { concentration, } \\
\text { (g/deciliter): } \\
\text { Mean } \pm \text { SD }\end{array}$ & $\begin{array}{l}32.31 \pm \\
2.25\end{array}$ & $\begin{array}{c}34.69 \pm \\
1.81\end{array}$ & $0.001 *$ \\
\hline $\begin{array}{l}\text { Reticulocyte } \\
\text { count }(\%) \text { : } \\
\text { Mean } \pm \text { SD }\end{array}$ & $\begin{array}{c}0.62 \pm \\
0.19\end{array}$ & $\begin{array}{c}0.84 \pm \\
0.17\end{array}$ & $0.001 *$ \\
\hline $\begin{array}{l}\text { Anemia type } \\
\text { according to RBC } \\
\text { indices(MCV, } \\
\text { MCH \&MCHC) } \\
\text { Microcytic- } \\
\text { Hypochromic } \\
\text { Normocytic- } \\
\text { Hypochromic } \\
\text { Normocytic- } \\
\text { Normochromic } \\
\text { Normal: complete } \\
\text { blood count. }\end{array}$ & $\begin{array}{c}7 \\
(14.0 \%) \\
7 \\
(14.0 \%) \\
36 \\
(72.0 \%) \\
0 \\
(0.0 \%)\end{array}$ & $\begin{array}{c}2 \\
(10.0 \%) \\
1 \\
(5.0 \%) \\
0 \\
(0.0 \%) \\
17 \\
(85.0 \%)\end{array}$ & $0.001 *$ \\
\hline
\end{tabular}

4- There were highly significant differences between patients and control in prevalence of anemia, it is higher in patients than control (Figure 1).

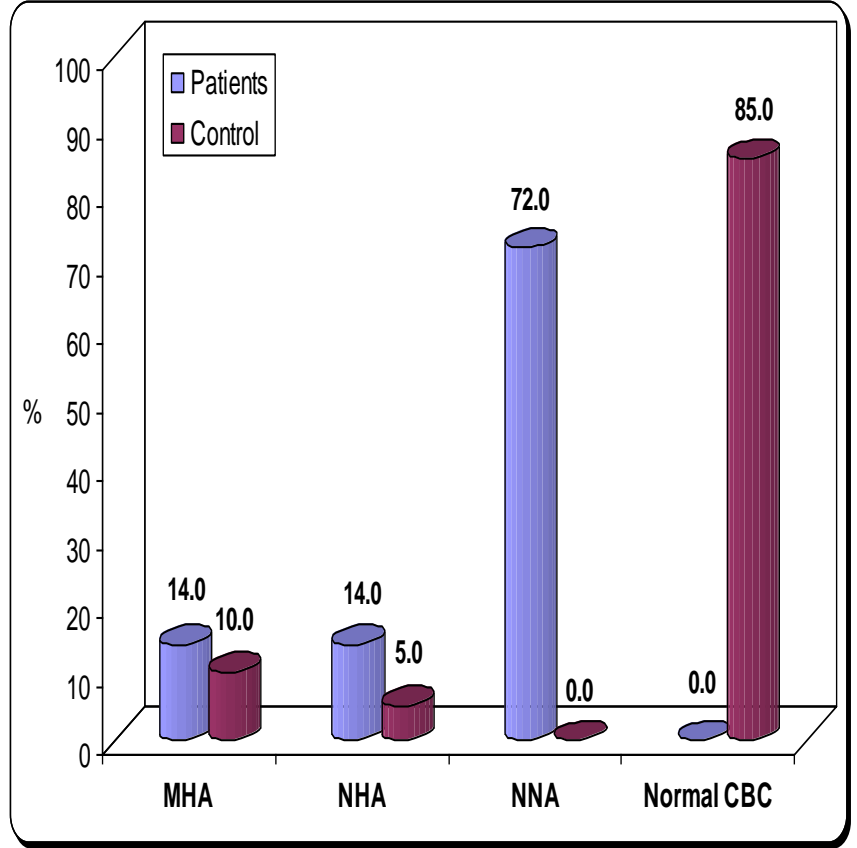

Figure (1): Anemia type according to RBC indices

5- There was highly significant difference between patients and control in: serum albumin and total protein (figure 2); blood urea and serum creatinine (Table 4); in GFR (Table 4); urinary albumin/creatinine ratio (Table 4) and in erythropoietin level (figure 3).

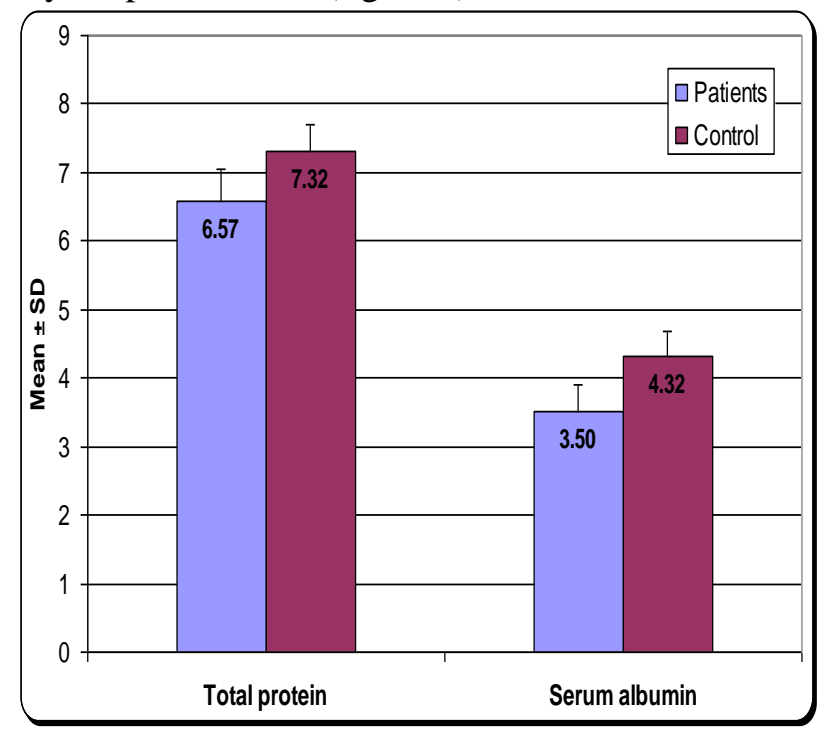

Figure (2): Serum total protein and albumin 
Table (4): Traditional kidney function tests,

Glomerular Filtration Rate and Urinary albumin/creatinine Ratio of both groups

\begin{tabular}{|l|l|l|l|}
\hline Renal profile & $\begin{array}{l}\text { Patients } \\
(\mathbf{n}=\mathbf{5 0})\end{array}$ & $\begin{array}{l}\text { Control } \\
(\mathbf{n}=\mathbf{2 0})\end{array}$ & P-value \\
\hline $\begin{array}{l}\text { Blood urea: } \\
\text { Mean } \pm \text { SD }\end{array}$ & $105.62 \pm 1.1$ & $\begin{array}{l}33.70 \pm \\
4.65\end{array}$ & $0.001 *$ \\
\hline $\begin{array}{l}\text { S. creatinine: } \\
\text { Mean } \pm \text { SD }\end{array}$ & $2.56 \pm 0.58$ & $0.79 \pm 0.1$ & $0.001 *$ \\
\hline $\begin{array}{l}\text { GFR: } \\
\text { Mean } \pm \text { SD }\end{array}$ & $\begin{array}{l}26.46 \pm \\
6.91\end{array}$ & $\begin{array}{l}100.97 \pm \\
9.87\end{array}$ & $0.001 *$ \\
\hline $\begin{array}{l}\text { Urinary } \\
\text { albumin/ } \\
\text { creatinine } \\
\text { Ratio: } \\
\text { Mean } \pm \text { SD }\end{array}$ & $390.34 \pm$ & $17.72 \pm$ & $0.0001 *$ \\
\hline
\end{tabular}

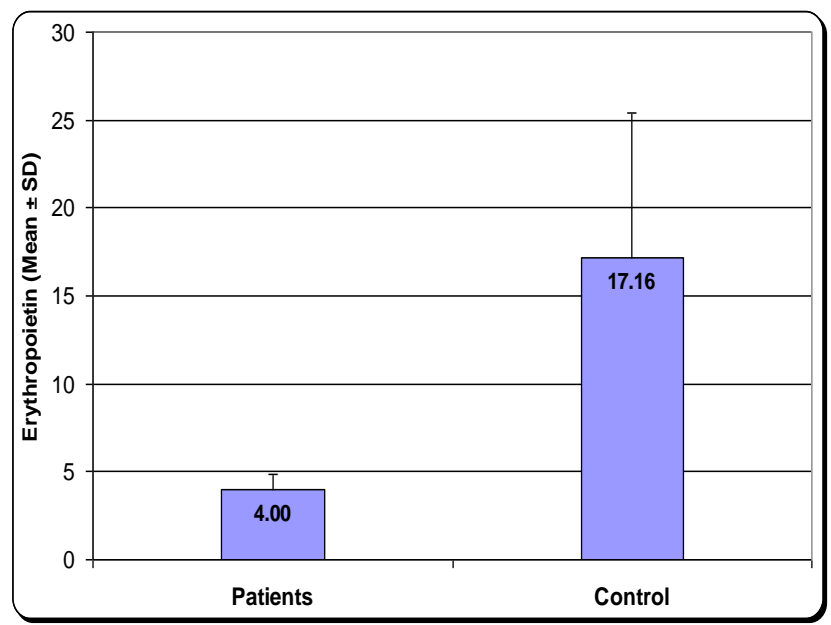

Figure (3) Erythropoietin of Patients and control

6- The prevalence of CKD stages (III and IV) among studied patients is shown in Table 5.

Table (5): Chronic kidney disease stages (III and IV)

\begin{tabular}{|l|r|r|}
\hline $\begin{array}{l}\text { Chronic Kidney } \\
\text { disease stage }\end{array}$ & $\begin{array}{l}\text { No. } \\
(\mathbf{n = 5 0})\end{array}$ & $\%$ \\
\hline Stage III & 16 & 32.0 \\
\hline Stage IV & 34 & 68.0 \\
\hline
\end{tabular}

In the current study, there were (Table 6);

7- Highly significant differences between patients and control in serum iron.

Significant differences between patients and control in TSAT and serum ferritin.

No significant differences between patients and control in TIBC.
Table (6): Iron profile of studied groups

\begin{tabular}{|c|c|c|c|}
\hline & $\begin{array}{c}\text { Patients } \\
(n=50)\end{array}$ & $\begin{array}{l}\text { Control } \\
(n=20)\end{array}$ & P-value \\
\hline $\begin{array}{l}\text { S. iron: } \\
\text { Mean } \pm \text { SD }\end{array}$ & $\begin{array}{c}52.38 \pm \\
2.40\end{array}$ & $\begin{array}{c}76.90 \pm \\
2.16\end{array}$ & $0.001 *$ \\
\hline $\begin{array}{l}\text { TIBC: } \\
\text { Mean } \pm \text { SD }\end{array}$ & $\begin{array}{c}244.40 \pm \\
58.99\end{array}$ & $\begin{array}{c}260.25 \pm \\
35.33\end{array}$ & 0.187 \\
\hline $\begin{array}{l}\text { TSAT: } \\
\text { Mean } \pm \text { SD }\end{array}$ & $\begin{array}{c}23.03 \pm \\
8.25\end{array}$ & $\begin{array}{c}30.28 \pm \\
1.35 \\
\end{array}$ & $0.009 *$ \\
\hline $\begin{array}{l}\text { S. ferritin: } \\
\text { Mean } \pm \text { SD }\end{array}$ & $\begin{array}{c}686.69 \pm \\
36.89\end{array}$ & $\begin{array}{c}387.71 \pm \\
86.37 \\
\end{array}$ & $0.001 *$ \\
\hline
\end{tabular}

TIBC: Total iron binding capacity, TSAT:

Transferrin saturation

8- The different grades of medical renal diseases in the studied patients as detected by abdominal ultrasonography are shown in Table 7.

Table (7): Abdominal ultra-sonogram of studied patients

\begin{tabular}{|l|c|c|}
\hline $\begin{array}{c}\text { Abdominal ultra- } \\
\text { sonogram }\end{array}$ & No. $(\mathbf{n = 5 0})$ & $\%$ \\
\hline Grade I MRD & 6 & 12.0 \\
\hline Grade II MRD & 20 & 40.0 \\
\hline Grade III MRD & 24 & 48.0 \\
\hline
\end{tabular}

9- There was significant positive correlation between hemoglobin $(\mathrm{Hb})$ level and glomerular filtration rate (GFR) (Figure 4).

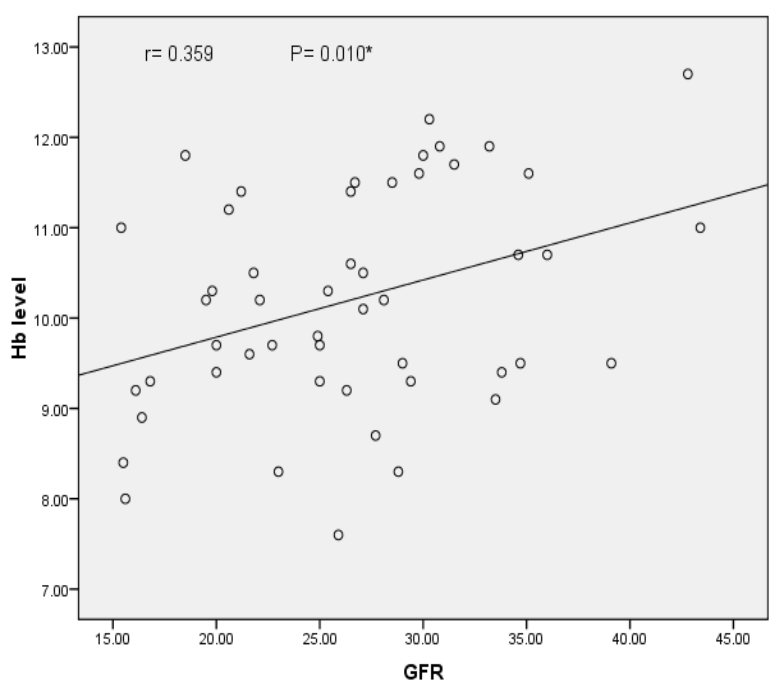

Figure (4): Correlation between hemoglobin (Hb) level and glomerular filtration rate (GFR)

10- There was highly significant positive correlation between erythropoietin level and glomerular filtration rate (GFR) (Figure 5). 


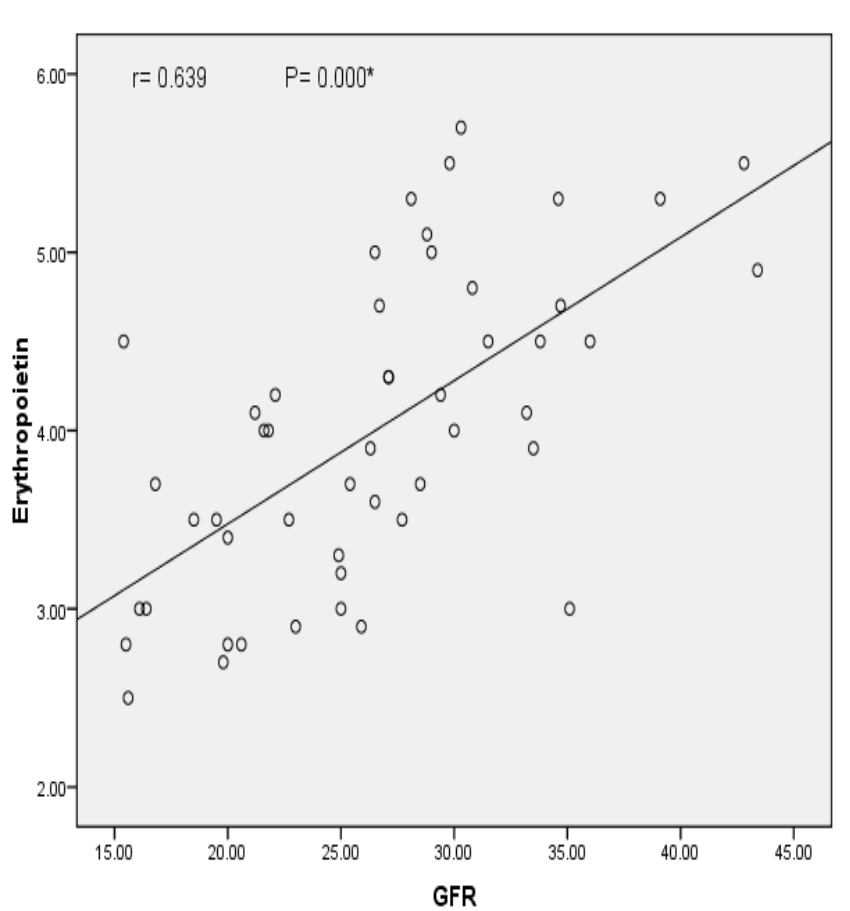

Figure (5): Correlation between erythropoietin level and glomerular filtration rate (GFR)

11-Prevalence of risk factors of anemia in the studied patients are shown in Table 8 .

Table (8) Prevalence of risk factors of anemia

\begin{tabular}{|l|r|l|}
\hline \multicolumn{1}{|l|}{ Risk factors } & & \\
& No. & $\%$ \\
& & \\
\hline Anorexia & & \\
\hline Positive occult blood in stool & 22 & 44.0 \\
\hline Increased CRP & $\mathbf{3}$ & $\mathbf{6 . 0}$ \\
\hline Increased ESR & 50 & 100.0 \\
\hline Increased Serum Ferritin & $\mathbf{5 0}$ & $\mathbf{1 0 0 . 0}$ \\
\hline Increased Blood urea & 50 & $\mathbf{1 0 0 . 0}$ \\
\hline Increased Serum creatinine & 50 & 100.0 \\
\hline Decreased GFR & 50 & 100.0 \\
\hline Erythropoietin deficiency & 27 & $\mathbf{5 4 . 0}$ \\
\hline
\end{tabular}

12-There was highly significant inverse correlation between number of risk factors and hemoglobin level. The more increase in the number of risk factors of anemia in renal patients, the more is the decrease in hemoglobin level (Figure 6).

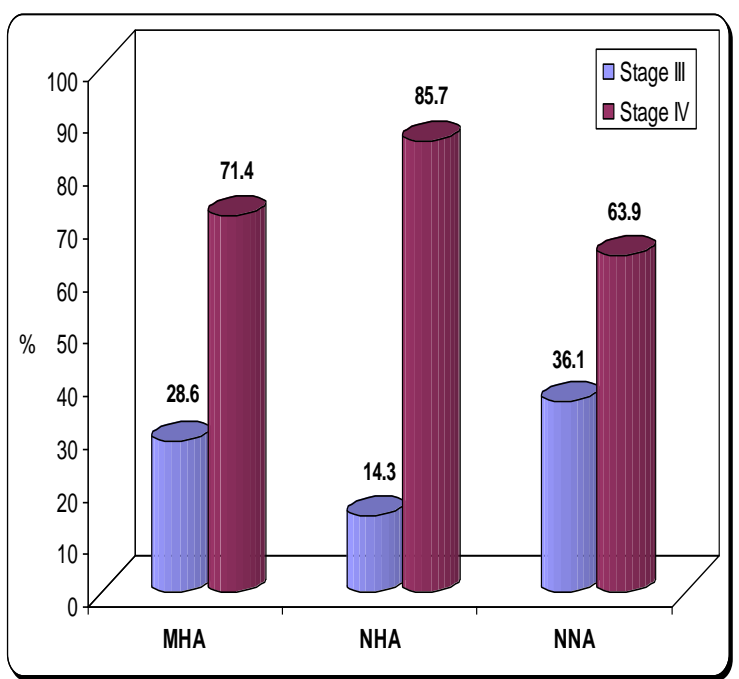

Figure (6): Correlation between number of risk factors of anemia in CKD and $\mathrm{Hb}$ level

13-The relation between type of anemia and CKD stage in the studied patients was as follows Among patients of microcytic-hypochromic anemia (MHA); 2 patients (28.6\%) are stage III CKD while 5 patients $(71.4 \%)$ are stage IV CKD.

- Among those of normocytic-hypochromic anemia (NHA); 1 patient (14.3\%) is stage III CKD while 6 patients $(85.7 \%)$ are stage IV CKD.

- Among patients of normocytic-normochromic anemia (NNA); 13 patients $(36.1 \%)$ are stage III CKD while 23 patients $(63.9 \%)$ are stage IV CKD.

MHA, NHA and NNA all are present in studied patients, but the prevalence of every type is increasing on transition from stage III to Stage IV. (Figure 7)

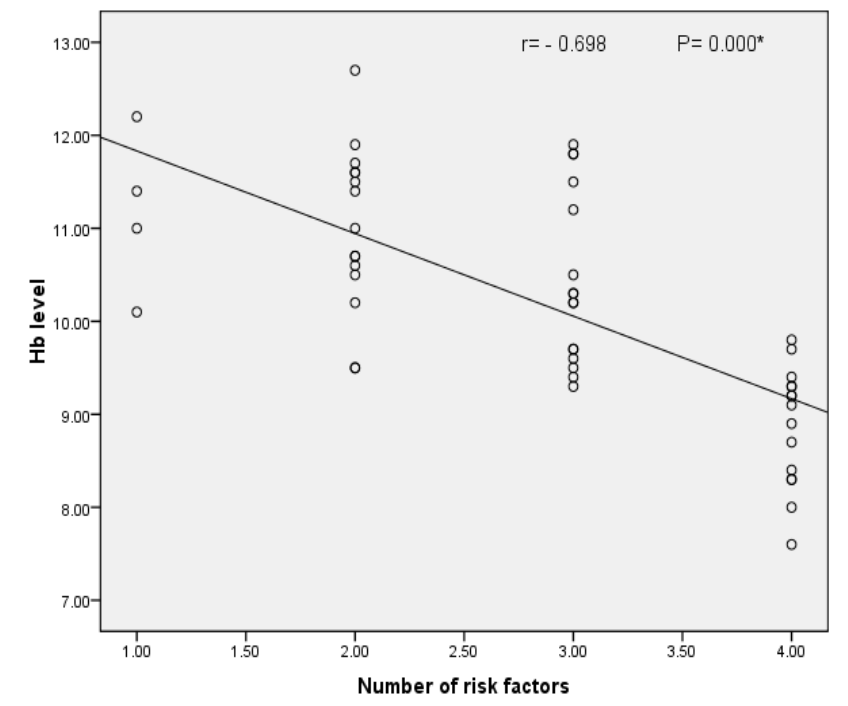

Figure (7): Relation between type of anemia and CKD stage in studied patients 


\section{DISCUSSION}

Anemia is strongly predictive of complications and death from cardiovascular causes in patients with chronic kidney disease ${ }^{(5)}$. The morbidity and mortality depend greatly on the underlying etiology of the patient's anemia as well as the stage of the disease, whether early or advanced. In fact, in individuals with advanced stages of chronic kidney disease, the etiology of anemia tends to be multifactorial ${ }^{(6)}$.

By doing abdominal ultrasonography (US) for studied patients to detect the underlying cause and as evidence of chronicity of kidney disease we found that; different grades of medical renal disease (MRD) were present among the studied patients as follows: 6 patients (12\%) were grade I MRD, 20 patients (40\%) were grade II MRD, and 24 patients (48\%) were grade III MRD. These results agree with Chen et al $^{(7)}$ who found same changes in US among the studied patients of CKD and were associated with laboratory results reflecting renal damages.

In our study; DM and HTN were present equally in $(52 \%)$ of patients followed by IHD, SLE, RA and RHD. This result was in agreement with Yali et al. ${ }^{(8)}$ who reported that diabetes and hypertension are the most common causes of CKD followed by other conditions that can damage the kidneys and cause CKD. Hypertension is a well-established cause, a common complication, and an important risk factor for progression of renal disease. Controlling hypertension is the most important intervention to slow the progression of renal disease ${ }^{(\boldsymbol{9})}$.

Diabetes is a common cause of chronic renal disease. Effective control of blood glucose and blood pressure reduces the renal complications of diabetes. Meticulous control of blood glucose was conclusively shown to reduce the development of microalbuminuria by $35 \%$ in type 1 diabetes (diabetes control and complications trial) and in type 2 diabetes (United Kingdom prospective diabetes study) ${ }^{(\mathbf{1 0})}$.

Moisseienko and Al'ianova (11) revealed that anorexia was one of the most common gastroenterological symptoms in CKD. In the current study anorexia was found only in (44\%) of patients and this can be explained by inclusion of CKD patients and those also on hemodialysis in the previous study.

In our study; pallor, facial puffiness and lower limbs edema were present in the studied patients with percentages of $90 \%, 42 \%$ and $38 \%$ respectively, while other clinical signs that were present in the patients including basal lung crepitation, mitral regurge, and malar flush and cushioned face were occurring in the percentages of $16 \%, 6 \%, 2 \%$ and $2 \%$ respectively. These results disagree with Levin and Stevens ${ }^{(12)}$ who reported that; facial puffiness followed by lower limbs edema are the most common clinical presentation in CKD patients in percentage of $55 \%$ and $43 \%$ respectively.

In the current study; occult blood in stool was present in 3 patients equal to a percentage of $(6 \%)$ while it was absent in 47 patients (94\%). These results disagree with Bini et al. ${ }^{(13)}$ who reported positive fecal occult blood test in $32.8 \%$ of 497 subjects with stage $2 / 3 \mathrm{CKD}$ and $42.6 \%$ of 197 patients with stage 4/5 CKD $(\mathrm{P}<0.001)$, compared to patients with none/stage $1 \mathrm{CKD}$. This disagreement can be explained by the large number of patients in addition to stage 2 and 5 CKD patients that were included in the last study.

Our present study revealed highly significant differences between patients and control groups in hemoglobin $(\mathrm{Hb})$ level, $\mathrm{P}$ value $=0.001$, Hb level was higher in control group. These results agree with Martínez et al. ${ }^{\left({ }^{(14)}\right.}$ study, which included 267 patients of stages 3, 4 and $5 \mathrm{CKD}$, not on dialysis, most of them were in CKD stages 3 and 4, the mean hemoglobin levels in these patients before starting ESA treatment was $10.2 \pm 0.9 \mathrm{~g} / \mathrm{dL}$.

The current study revealed highly significant differences between patients and control in the prevalence of anemia, it was higher in patients than control. The all 50 patients $(100 \%)$ had anemia while only 3 subjects (15\%) of control had anemia and 17 subjects $(85 \%)$ had normal CBC. Among patients group 36 patients (72\%) had normocyticnormochromic anemia (NNA), 7 patients (14\%) had normocytic-hypochromic anemia (NHA) and 7 patients (14\%) had microcytic-hypochromic anemia (MHA), while in the control group only 2 individuals (10\%) had MHA and 1 individual (5\%) had NHA. These results agree with Talwar et al. ${ }^{(15)}$ who found $100 \%$ of advanced CKD patients not receiving treatment had anemia, the prevalence of NNA, NHA, MHA occurred in a percentage of $72 \%, 9 \%, 19 \%$ respectively, while Afshar et al. (16) reported that; among 46 predialysis patients $75 \%$ had anemia and $25 \%$ had normal CBC. By studying the morphological pattern of anemia they found NNA and MHA were occurring in a percentage of $80 \%$ and $15 \%$ frequently and $5 \%$ had macrocytic anemia.

Our study revealed highly significant lower mean GFR in the studied patients compared to the control group, this result was in agreement with Stevens et al. ${ }^{(17)}$ who reported that; patients with advanced stages CKD had lower mean GFR compared to control due to marked reduction in the functioning units of the kidney.

In the current study (by dipstick test) we found that $70 \%$ of the studied patients had overt proteinuria in different grades, while $30 \%$ had no proteinuria but they had moderate albuminuria assessed by increased 
urinary albumin : creatinine ratio. These results agree with study of Davidson and Smiley ${ }^{(\mathbf{1 8})}$ which include 70 CKD patients, 19 diabetic and 51 non diabetic. 54 patients $(77 \%)$ had proteinuria with dipstick test, 12 patients $(17 \%)$ had trace positive for protein and 42 patients $(60 \%)$ had proteinuria more than or equal $1+$, also albumin : creatinine ratios were measured in urine samples and they conclude that; in contrast to the recommendations of the American Diabetes Association and the National Kidney Foundation, dipstick positive proteinuria of more than or equal to (1+) can substitute for an albumin: creatinine ratio

In the present study, we found highly significant differences in serum iron, it was lower in the studied patients compared to control, the mean serum iron \pm SD was $(52.38 \pm 12.40 \mathrm{microgram} / \mathrm{dl})$ and $(76.90 \pm 22.16 \mathrm{microgram} / \mathrm{dl})$ in patients and control respectively. These results are in agreement with Arogundade et $\boldsymbol{a l} .{ }^{(19)}$ who found in the study including 60 predialysis CKD patients that; anemia is very common in the predialysis CKD population and the prevalence of iron deficiency is high, the mean serum iron $\pm \mathrm{SD}$ was $(50.22 \pm 11.52$ microgram $/ \mathrm{dl})$ before starting treatment with intravenous and oral iron. We also found significant differences in TSAT\% between patients and control, it was lower among the studied patients, but there was no significant differences between both in TIBC. These results agree with Chung $\boldsymbol{e t}$ al. ${ }^{(20)}$ who reported low TSAT\% in non-dialysis stage 3-5 CKD patients but also no significant decrease in TIBC among the same patients group. Also we found significant differences between patients and control in serum ferritin, its mean was higher in the studied patients. This result in agreement with Meynard et al. (21) who found elevated serum ferritin level in predialysis CKD patients due to infection and inflammation.

Erythropoietin (EPO) in normal adult ranged between $4.1-19.5 \mathrm{mlu} / \mathrm{ml}$ and decreases as the CKD progresses. EPO measurement is not routinely done for diagnosis of anemia in CKD ${ }^{(22)}$. Our present study revealed highly significant differences in serum erythropoietin (EPO) level between patients and control. This result agree with Gouva et al. ${ }^{(23)}$, who reported EPO deficiency in chronic kidney disease, which is a functional response to a decreased glomerular filtration rate and the specialized peritubular cells that produce EPO are partially or completely depleted or injured as renal disease progresses. The specialized peritubular cells that produce EPO are partially or completely depleted or injured as renal disease progresses, so that EPO production is inappropriately low relative to the degree of anemia. EPO is produced when its gene is transcribed, in a process that depends on the binding of a molecule called hypoxia-inducible factor 1 alpha to the hypoxia-responsive element on the erythropoietin gene ${ }^{(23)}$.
In our study, we found significant positive correlation between hemoglobin $(\mathrm{Hb})$ level and glomerular filtration rate (GFR). This result agree with Zarzecki et al. (24) who found significant positive correlation between $\mathrm{Hb}$ level and GFR in different stages of chronic renal failure. Also Afshar et al. ${ }^{(16)}$, reported same result in the study were including 46 predialysis patients. We also found highly significant positive correlation between erythropoietin level and GFR. This result agree with Gouva et al. ${ }^{(23)}$, who reported highly significant positive correlation between erythropoietin level and GFR in CKD patients not receiving renal replacement therapy.

By studying the prevalence of different risk factors causing anemia among the patients group we found that; anorexia was present in 22 patients (44\%) while occult blood in stool was positive in 3 patients (6\%). Increased levels of CRP, ESR and serum ferritin as indicators of inflammation were present in 50 patients $(100 \%), 50$ patients $(100 \%)$ and 40 patients $(80 \%)$ respectively. Also the indicators of "uremic milieu" including increased level of blood urea and serum creatinine in addition to decreased level of GFR, all were present in the 50 patients $(100 \%)$. Erythropoietin deficiency also was present in 27 patients $(54 \%)$.

The present study revealed highly significant inverse correlation between number of risk factors and hemoglobin level. The more prevalence of risk factors of anemia in renal patients, the more is the decrease in hemoglobin level. This result is in agreement with Magwood $\boldsymbol{e t} \boldsymbol{a l} .{ }^{(25)}$, who reported more reduction in $\mathrm{Hb}$ level among CKD patients as the prevalence of different causes of anemia is increasing.

\section{CONCLUSION AND RECOMMENDATIONS}

1- Our study concluded that anemia in pre ESRD is multifactorial and the prevalence of different risk factors is inversely correlated with hemoglobin level. The normocytic-normochromic anemia (NNA) is the most common morphological pattern in renal patients followed by normocytic-hypochromic and microcytic-hypochromic types.

2-Anemia may develop early in CKD patients and before the onset of uremic symptoms, so once renal impairment is diagnosed and GFR $<60 \mathrm{ml} / \mathrm{min}$ the patients should be screened for anemia by regular $\mathrm{CBC}$ and iron profile may be needed.

\section{REFERENCES}

1. Mathew TH, Johnson DW, Jones GR (2007): Chronic kidney disease and automatic reporting of estimated glomerular filtration rate: revised recommendations. The Medical Journal of Australia, 187 (8): 459-63.

2. Keener J, Sneyd J (2004): Renal Physiology". In Marsden, J.E. Mathematical Physiology (Book). 
Interdisciplinary Mathematics. Mathematical Biology Vol. 8. Sirovich, Wiggins (1st ed.). https://www.math.auckland.ac.nz/ sneyd/Physiol_Boo k/preface.pdf

3. Means RT (2003): Recent developments in the anemia of chronic disease. Curr Hematol Rep., 2(2):116-21.

4. Zaritsky J, Young B, Wang HJ et al. (2009): Hepcidin--a potential novel biomarker for iron status in chronic kidney disease. Clin J Am Soc Nephrol., 4(6):1051-6.

5. Weiner DE, Tighiouart H, Stark PC(2004): Kidney disease as a risk factor for recurrent cardiovascular disease and mortality. Am J Kidney, 44:198-206.

6. McClellan W, Aronoff SL, Bolton WK (2004): The prevalence of anemia in patients with chronic kidney disease. Curr Med Res Opin., 20(9):1501-10.

7. Chen HY, Zhang JY, Xiang X et al. ( 2014): Contrastenhanced ultrasound parameters for early chronic kidney diseases and their associations with laboratory results. Sichuan Da Xue Xue Bao Yi Xue Ban., 45(6):988-91.

8. Yali Cao, Wenge Li, Guannan Y et al. (2012): Diabetes and hypertension have become leading causes of CKD in Chinese elderly patients: a comparison between 1990-1991 and 2009-2010. International Urology and Nephrology, 44: 1269-1276.

9. Chobanian AV, Barkris GL, Black HR (2003): Seventh report of the Joint National Committee on Prevention, Detection, Evaluation, and Treatment of High Blood pressure. Hypertension, 42:1206-1252.

10. Solomon SD, Uno H, Lewis EF et al. (2010): Erythropoietic response and outcomes in kidney disease and type 2 diabetes. N Engl J Med., 363(12):1146-55.

11. Moǐseienko VO, Al'ianova TS (2014): Gastrointestinal disorders in patients with renal impairment. Lik Sprava, 11:10-5.

12. Levin A, Stevens LA (2005): Executing change in the management of chronic kidney disease: perspectives on guidelines and practice. Med Clin North Am., 89(3):701-9.

13. Bini EJ, Kinkhabwala A, Goldfarb DS (2006): Predictive value of a positive fecal occult blood test increases as the severity of CKD worsens. Am J Kidney Dis., 48(4):580-6.

14. Martínez-Castelao A, Cases A, Coll E (2015): Investigators of the Micenas II study. C.E.R.A. administered once monthly corrects and maintains stable hemoglobin levels in chronic kidney disease patients not on dialysis: the observational study MICENAS II. Nefrologia, 35(1):80-6.

15. Talwar UK, Gupta HL, Narayana S (2002): Clinical haematological profile in chronic renal failure. J Assoc Physicians India, 50:228-33.

16. Afshar R, Sanavi S, Salimi J et al. (2010): Hematological profile of chronic kidney disease patients in Iran, in pre-dialysis stages and after initiation of hemodialysis. Saudi J Kidney Dis Transpl., 21(2):36871.

17. Stevens LA, Coresh J, Greene $\mathbf{T}$ et al. (2006): Assessing kidney function--measured and estimated glomerular filtration rate. The New England $\mathrm{J}$ of Medicine, 354 (23): 2473-83.

18. Davidson MB, Smiley JF (1999): Relationship between dipstick positive proteinuria and albumin: creatinine ratios. J Diabetes Complications, 13(1):52-5.

19. Arogundade FA, Soyinka FO, Sanusi AA et al. (2013): Iron status and benefit of the use of parenteral iron therapy in pre-dialysis chronic kidney disease patients. Niger Postgrad Med J., 20(4):299-304.

20. Chung $M$, Moorthy D, Hadar $\mathrm{N}$ et al. (2012): Biomarkers for Assessing and Managing Iron Deficiency Anemia in Late-Stage Chronic Kidney Disease. AHRQ Comparative Effectiveness Reviews, 12(3)217-25.

21. Meynard D, Kautz L, Darnaud V (2009): Lack of the bone morphogenetic protein BMP6 induces massive iron overload. Nat Genet., 41: 478-481.

22. Locatelli F, Aljama P, Barany P (2004): Revised European best practice guidelines for the management of anaemia in patients with chronic renal failure. Nephrol Dial Transplant, 19(2):1-47.

23. Gouva Ch, Papavasiliou E, Katopodis KP et al. (2006): Effect of Erythropoietin on Serum pafacetylhydrolase in patients with Chronic Renal Failure. Nephrology Dialysis Transplantation, 21(5):1270-77.

24. Zarzecki M, Chudek J, Kukla M et al. (2004): Prevalence of anemia, calcium-phosphorus abnormalities and metabolic acidosis in different stages of chronic renal failure. Pol Arch Med Wewn., 112(4):1211-9.

Magwood JS, Lebby A, Chen B et al. (2013): Emerging drugs for treatment of anemia of chronic kidney disease. Expert Opin Emerg Drugs, 18(4):421-9. 